\title{
Regional Customs Collaboration Development Strategy in the Background of the Belt and Road Initiative
}

\author{
Lan Teng $^{1, a}$, Zhenji Zhang ${ }^{1, b}$, Qiwen Du ${ }^{1, c}$, Yunfang Ma ${ }^{1, d}$ \\ ${ }^{1}$ School of Management and Economics, Beijing Jiaotong University, No.3 Shangyuancun, Haidian \\ District, Beijing, 100044, China \\ aaugtl@hotmail.com, bzjzhang@bjtu.edu.cn, '14113135@bjtu.edu.cn, 'yunfangm@bjtu.edu.cn
}

Keywords: the Belt and Road Initiative, customs union, development strategy, collaboration

\begin{abstract}
The Belt and Road Initiative is one of China's greatest international economic directions, aiming at economic development in Asia, Africa and Europe, which are the main economic members all over the world. We analyze the developing background of the Belt and Road Initiative, combining with the initial function of customs and the appeal with the Belt and Road Initiative and analyzing the collaboration developing problems they face. Current situation of customs confronting are analyzed from the perspective of mutual infrastructure construction, international cooperation, and holding summit forums among different countries. Previous experience of EUCU could be used for reference on the customs cooperation. The customs cooperation could be an important booster for the development among related countries. However, the collaboration of customs also face many barriers, such as different political policies of different countries, lack of uniformed policies and contracts.
\end{abstract}

\section{Introduction}

The Belt and Road Initiative is the abbreviation of "Silk Road Economic Bet" and " $21^{\text {st }}$ Century Maritime Silk Road”. "Silk Road Economic Bet” was raised by President Xi making a speech in Nazarbayev University of Kazakhstan, which means the regional cooperation between China and countries all over western-Asian in the scope of Ancient Silk Road including Shaanxi, Gansu, Qinghai, Ningxia and Xinjiang etc. five provinces in northwest of China and Chongqing, Sichuan, Yunnan and Guangxi etc. four provinces/cities. " $21^{\text {st }}$ Century Maritime Silk Road” was put forward by President Xi visiting Asean countries, which makes the market chain of several main economic sectors including Asean, South-Asia, West-Asia, North-Africa, and Europe. The development of the Road faces to the strategic cooperation economic belt of South Sea, Pacific Ocean, and Indian Ocean, and the long developing target of economic and trade integration. The Belt and Road Initiative was written into comprehensive reform blueprint adopted by Party leadership in the year of 2013 as a key policy priority before 2020 [1-2].

"The vision and action of promoting the co-construction of Silk Road and Economic Belt and Maritime Silk Road” published by National Development and Reform Commission, Ministry of Foreign Affairs, and Ministry of Commerce. The cooperation focuses on the perspectives of policy, facility, trade, finance and public minds to promote the freely flowing of economical elements, effective allocation of resources, and deep integration of market. Pushing forward the collaboration of economic policies. To carry out regional cooperation with greater scope, higher level and deeper layer, and jointly build an open, inclusive, balanced and regional economic cooperation framework. As the national entry-exit supervision department, customs department establish a special leading 
group to promote the customs The Belt and Road Initiative construction leading group. The focus from the "smooth channels, improve trade, and deepen cooperation" three aspects to launch 16 measures to strengthen international cooperation in cross sectoral cooperation and inter-regional cooperation, promoting interoperability, omni-directional, three-dimensional and networked to realize truly "off the world"[2].

It seems from the characteristics of the customs itself, due to the The Belt and Road Initiative involved a wide range of regional countries and the development of it can't continue without the support of the customs department, so One Belt and One Road customs under the background of regional coordinated development is to protect the safety of import and export trade to ensure the efficient operation. First, an important support for the development of "The Belt and Road" is the customs supervision and management departments of national import and export whose functions are to safeguard national economic security, maintain international trade order, reflect the situation of foreign trade, with the implementation of macro-control policies, as the national opening and an important gateway to the global supply chain key nodes, strengthen the important international conditions cooperation is not only the interconnection, and is also an important support to build a win-win. The function of customs is closely related to the open economic development of the country. In recent years, the process of China customs' international cooperation has been continuously pushed forward international cooperation, promote global trade security and facilitation. Second, to lay the foundation for international exchanges and cooperation, Chinese customs has gradually conformed to international standards and learned to use international rules, participated in some important international affairs, accurately grasped international customs rules, which are all laid foundation to carry out The Belt and Road Initiative. Third, to create good environment for cooperation, Chinese customs has made some achievements in bilateral, multilateral and regional customs cooperation under the framework of cooperation. In development cooperation area they have made some progress that local customs in different areas complement each other's advantages, strengthening cooperation and exchanges, and creating good environment for international cooperation [3,4].

In this paper, we analyze the current situation in the background of The Belt and Road initiative, combining the customs' function and demands with One Belt and One Road initiative analyzing collaborative development issues in different regions, putting forward the countermeasures for the current situation and to enhance the national customs along the level of cooperation aiming at improving the trade investment facilitation and enhance regional economic competitiveness, and safeguard the security of global trade.

\section{Collaborative Development reference of Customs: European Union Customs Union (EUCU)}

Customs union, established in 1958, is a principal component of European Economic Community. EUCU is the basic sector of the European Union to develop and implement tax policies for the citizens, business and member states of the European Union. Two levels of general solutions both European and international taxation and customs in the field to members and managers, so that they can deal with the current economic, social and environmental challenges. The aim of EUCU is to simplify customs tax management rules and procedures, assist managing the existing legislation of EU tax and tariff, manage and protect EU's external borders, combat illegal trade flows and to strengthen the safety management of the international supply chain, value-added tax system, the formulation of a simplified continuous modernization, committed to the restricting the distortions 
caused by each member of the tax system and. In international level, to improve the exchange of information and transparency to ensure taxation, customs and the community in the business policy, development assistance and "Europe" development, focus in the implementation of energy tax, the development of low carbon economy, helping member states to combat fraud and tax evasion. In order to achieve these goals, the European Union customs Federation has adopted a legislative and non-legislative approach, focusing on the sharing of information between the European Commission and member states. In 2013, the interactive scheme based on computer system has become an important technical means to supervise trade fraud.

Illegal international trade is not only the barrier to EU economic development, but also reducing the social welfare, the EU customs union as one of the three pillars of the European Union, has been playing an indelible role. The customs are playing a key lubricant role for international trade and security, especially for the year 300 million tickets and 3 trillion and 500 billion Euros worth of goods customs clearance supervision. It is necessary for EU customs to optimize the use of resources. Customs risk management level needs to be improved without affecting the security or disrupt the premise of legal trade, so that the customs can effectively make the best the deployment, at any time to deal with related risk.

\section{Analysis on customs collaboration current situation of under the Belt and Road Initiative}

\subsection{Present main actions [5-8]}

3.1.1 CIS Customs Union international cross-border e-commerce integrated service center has completed

In June 2015, the CIS Customs Union International cross-border e-commerce service center was built in Huludao Xingcheng Dahongmen logistics park. The center of the joint Sino Russian cross-border e-commerce service platform, e-commerce network in Northeast Asia and Russia. The unique advantages of integrated service center has the clearance Easy Access. Customs clearance and logistics synchronization, simplify customs procedures, improve the efficiency of the flow of goods, customs clearance and reduce risk.

\subsubsection{Nanning Customs cooperates with customs of three provinces of Vietnam}

In 2012, Nanning customs, Vietnam Lang Son, Quang Ninh, Kopin three provinces Bureau of customs border talks was held for the first time. In June 2015, the second border talks was held. The specific content of cooperation include the followings. First, the customs will cooperate to enhance the Sino Vietnamese trade facilitation to provide convenience for both import and export enterprises. Second, the establishment bi-lateral normalization mechanism. Third, the two sides expand cooperation and deepen the exchange of information about customs laws and regulations, import and export of goods, smuggling suspects etc..

\subsubsection{Cooperation of Fujian and Taiwan Customs}

Xiamen Port is an important foreign trade port of Maritime Silk Road. Xiamen is also one of the first four special zones, so Xiamen has many advantages in the new generation of information technology, Taiwan trade, international trade, financial services, modern logistics and other aspects, taking the advantage in industrial transformation, trade regulation expanding the open sea and air transport services, innovation deepening cross-strait industrial cooperation. Both Fujian and Taiwan also cooperate in the customs, provide convenience for the development of the Free Trade Zone and the Belt and Road construction, creating a win-win cooperation.

\subsubsection{Customs Summit Forum of the Belt and Road Initiative}

In May 27, 2015, “The Belt and Road” customs summit forum was held in Xi'an with the 
theme of "interoperability and build win-win". The General Administration of Customs proposed 16 measures to support and promote the construction of Silk Road Economic Belt and 21st Century Maritime Silk Road vision and action related and be refined into specific operational initiatives.

\subsection{Disadvantages and challenges}

Firstly, the function department is dispersed and the mechanism related is not integrity. The resources to foreign countries are dispersed and lack of integration mechanism. However, customs home and abroad need to cooperate with each other and expand the cooperation scope in the area of important projects by carrying out all-round cooperation and coordination mechanism. Secondly, the lack of policy support. With the trade volume growth of import and export, the business volume growth of customs department growth is obviously. Although the Belt and Road Initiative has been an important project in China, the related policy is not integrity and there are big amount of gap in finance and human resource and it is hard for customs to adapt to the current form. Third, the lack of complete top level design. General secretary Xi Jinping pointed out that the work of foreign affairs should be three-dimensional thinking, three-dimensional operation, strengthen top-level design, do a good job of strategic operations, and implement the bottom thinking. The lack of a complete top-level design to analyze is an important reason in the developing. Fourth, the lack of theoretical support and talent protection. The customs in international management as a guide to the foreign affairs work is still in the blank stage. The related theory of foreign affairs and cooperation has been far behind practical work. However, theoretical directions is the guide of action, the lag of theoretical research will restrict the development of practice. At the same time, diplomatic work needs talented people with special requirement, the promotion of professional quality of staff still has a long way to go.

\section{Countermeasures of customs collaboration}

"The Belt and Road Initiative" is the main mode of innovation to economic cooperation. The core is on political, social, cultural and other aspects of cooperation for the protection and promotion of China and countries along, eventually realizing the common development of regional integration, putting forward the policy communication, roads unicom, wool clothing, smooth circulation of money, the people connected. As an important department of import and export, customs is an important basis for support services to the "The Belt and Road Initiative". From the EUCU's experience, analyzing of China's customs cooperative development status and existing problems, we put forward the following countermeasures and measures on coordinated development of regional customs cooperation.

\subsection{Countermeasures}

4.1.1 Make clear the principle of cooperation and make overall consideration of the differences between different countries

There are many countries along the Silk Road, so it is essential to fully grasp the basic situation along the country and customs, and to understand the history and present situation of different customs including trade policies and customs law according to the different cultural background and way of thinking.

\subsubsection{Strengthen theoretical research to guide practical activities}

We should study the diplomatic theory and relevant policies of the Party Central Committee to make clear the overall layout and strategic deployment of the national diplomacy, and ensure that the international cooperation carried out in the right direction. In addition, following up of the World Customs Organization (WCO) and the World Trade Organization (WTO) to promote the 
combination of Silk Road Economic Belt and in 21st century in the construction of the new Silk Road.

\subsubsection{Strengthen top-level design based on national policy}

International customs cooperation should stand on the processing and analysis of strategic and global perspective, strengthening foreign cooperation work of the top-level design from the perspective of strategic importance, strategic planning.

\subsubsection{Strengthen infrastructure construction and internal \& external coordination}

The main challenge of customs cooperation in Silk Road Economic construction is to solve the sharp contradiction between the demand of development and the restriction of development ability , so the need to strengthen infrastructure construction. On the one hand, lay the foundation for good cooperation is to improve the system construction.

\subsection{Measures}

\subsubsection{Port construction support}

Efforts to play the role of logistics as a key port node channel interconnection, in the preparation of the national port development plan and the annual plan hearing port opening priority project areas along the Belt and Road Initiative also innovate in port management mode innovation through the port reform legislation. Promote the "one-stop" operation, and implement new series model of customs clearance.

\subsubsection{Channel construction}

Channel construction includes the construction of logistics corridor and the construction of large channel for maritime transportation. First, to promote the construction of international logistics channels means to improve the cooperation mechanism of customs inland and coastal border, air transport hub, railway and highway intermodal logistics supervision center, obtain the whole information through various multimodal logistics network. Second, to promote the construction of large channel for marine transportation means to support the key coastal city ports to carry out the transfer set up business, optimize and improve the international transfer, and import/export customs supervision model.

\subsubsection{Promote economic and trade cooperation}

Including support around the expanding opening up, support enterprises to "go out" and support the development of new business format, drive along the country and build a free trade area, play areas under special customs supervision and bonded policy advantage.

\subsubsection{Strengthen the mechanism and talent construction}

It includes abundant contents and mechanism for international cooperation, the focus to promote bilateral cooperation, deepen the international customs area of international cooperation, actively participate in multilateral cooperation continue to expand customs influence, to create a number of cooperation projects to promote interoperability.

\section{Acknowledgement}

This research is supported the project of “City Logistics” held by National Natural Science Fund Committee of China (No. 71390334). This work is also partially supported by Beijing Logistics Informatics Research Base. The authors thank the great support of International Center for Informatics Research of Beijing Jiaotong University. 


\section{References}

[1] Central Committee of the Communist Party of China (Central Committee) (2013)). Decision of the Central Committee of the Communist Party of China on some major issues concerning comprehensively deepening the reform $[\mathrm{M}]$. Third plenum of the 18th National Congress, November 2013, Beijing.

[2] National Development and Reform Commission (NDRC), \& Foreign Ministry and Ministry of Commerce (with approval by the State Council) (2015n). Vision and action for jointly building the silk road Economic Belt and the 21st century maritime silk road. Bo'ao forum, March 2015, Hainan.

[3] Huang Y. Understanding China's Belt \& Road Initiative: Motivation, framework and assessment [J]. China Economic Review, 2016, 40:314-321.

[4] Swaine M D. Chinese Views and Commentary on the "One Belt, One Road" Initiative [J]. China Leadership Monitor, 2015.

[5] Cheng L K, Fleisher B M, Huang K X D, et al. Three questions on China's "Belt and Road Initiative” [J]. China Economic Review, 2016, 40:309-313.

[6] Xinhua (2015). Belt and road initiative makes fruitful progress. December 28. Retrieved July 1, 2016, from http://www.chinadailyasia.com/chinafocus/2015-12/28/ content15364435.html

[7] Xinhua (2016a). China, Czech Republic pledge for strategic partnership, deep cooperation. March 30. Retrieved July 1, 2016, from http://en.xinfinance.com/html/ Policy/2016/209585.shtml

[8] Xinhua (2016b). Chronology of China's belt and road initiative. June 24. Retrieved July 1, 2016, from http://www.china.org.cn/china/Off_the_Wire/2016-06/24/ content_38741620.htm 